\section{Infant nutrition and subsequent risk of Type 2 (non-insulin-dependent) diabetes mellitus}

Dear Sir,

Hales and Barker [1] have pieced together a number of disparate observations to provide a fascinating and novel hypothesis on the aetiology of Type 2 (non-insulin-dependent) diabetes mellitus. Central to their hypothesis is the notion that beta-cell function is diminished as a result of under-nutrition at a critical point in the development of the islets of Langerhans during fetal and early infant life.

We are unable to reconcile this hypothesis to observations of increased insulin levels (in relation to Caucasian populations) in normal, glucose intolerant and diabetic individuals in developing populations, such as Pacific islanders [2], Australian Aborigines [3], American Indians [4] and Asian Indians [5]. According to Hales and Barker [1], these populations (or the individuals within them) are at increased risk of developing glucose intolerance with modernization, presumably because early under-nutrition resulting in beta-cell damage has left the pancreas unable to cope with the increased insulin requirements of the diet, obesity and reduced activity levels of a modern lifestyle.

However, the very populations with the greatest susceptibility to Type 2 diabetes, are those with the highest beta-cell function, based on their total immunoreactive insulin levels. Hales and colleagues $[1,6]$ claim that much of this "immunoreactive" insulin is biologically less active proinsulin and des 31,32split proinsulin. This appeared to be the case in newly diagnosed Type 2 diabetic patients, particularly $30 \mathrm{~min}$ after an oral glucose load [6], but is not the case in mild non-insulin-dependent diabetes [7]. If a high proportion of insulin in susceptible populations could be shown to be composed of physiologically inactive proinsulin and its split products, then the Hales and Barker hypothesis of relative insulin deficiency might still hold. To date, there is no confirmation that population differences in total insulin levels can be explained by differences in concentrations of true insulin compared to proinsulins.

Within populations, the Hales and Barker hypothesis also runs into difficulties. In several populations it has been shown that increased (not decreased) insulin levels (fasting, 2-h, etc.), predict deterioration in glucose tolerance from normal to impaired or to Type 2 diabetes [8-11]. While admittedly these studies need to be repeated measuring true insulin, they suggest that the beta cells of individuals with deteriorating glucose tolerance tend to have increased (but possibly still "abnormal") rather than decreased function. If it is only first phase secretion [12] that needs to be diminished to provide the susceptibility (and this is not outside the bounds of possibility), it is not clear that the "thrifty phenotype" hypothesis relating infant nutrition to pancreatic development adequately explains such a specific lesion.

Furthermore, we should point out that Hales and Barker have misinterpreted our data showing a recent decline in the incidence of glucose intolerance in the high prevalence Nauruan population [13]. We certainly did not attribute the recently observed changes in prevalence and incidence to natural selection - the time-course is obviously too short. Rather, we hypothesised that the reduction was due to the intensity of the epidemic and the fact that most of the genetically susceptible individuals had already "caught" the disease, leaving a relatively resistant group of individuals with normal glucose tolerance at the time of the most recent follow-up survey. Moreover, the decline in incidence did not occur only in younger age groups, presumed to have better nutrition, as incorrectly asserted by Hales and Barker. The decline in the incidence of impaired glucose tolerance and Type 2 diabetes amongst subjects with normal glucose tolerance at baseline occurred right across the age range (the age-specific data were not shown in the original article). In addition, while we have recently shown that fasting and post-load insulin concentrations, after adjusting for body mass index, are higher in Nauruans aged 8-
19 years than in older age groups, these high levels also predict subsequent deterioration in glucose tolerance [14]. Therefore, if pancreatic function has "improved" in young Nauruans as a result of better nutrition, it would appear that the result will have been to increase rather than decrease susceptibility to Type 2 diabetes.

In conclusion, Hales and Barker [1] have presented a provocative hypothesis and reviewed some intriguing data. At present, however, there are some major inconsistencies which need to be explained before the hypothesis can be given greater credence.

Yours sincerely,

G.K.Dowse, P.Z.Zimmet and K. G. M.M. Alberti

\section{References}

1. Hales CN, Barker DJP (1992) Type 2 (non-insulin-dependent) diabetes mellitus: the thrifty phenotype hypothesis. Diabetologia 35: 595-601

2. Zimmet $P$, Whitehouse $S$, Kiss $J$ (1979) Ethnic variability in the plasma insulin response to oral glucose in Polynesian and Micronesian subjects. Diabetes 28: 624-628

3. O'Dea K, Spargo RM, Nestel PJ (1982) Impact of westernization on carbohydrate and lipid metabolism in Australian Aborigines. Diabetologia 22: $148-153$

4. Aronoff SL, Bennett PH, Gorden P, Rushforth N, Miller M (1977) Unexplained hyperinsulinaemia in normal and "pre-diabetic" Pima Indians compared with normal Caucasians. An example of racial differences in insulin secretion. Diabetes 26: 827-840

5. Mohan V, Sharp PS, Cloke HR, Burrin JM, Schumer B, Kohner EM (1986) Serum immunoreactive insulin responses to a glucose load in Asian Indian and European type 2 (non-insulin-dependent) diabetic patients and control subjects. Diabetologia 29:235-237

6. Temple RC, Carrington CA, Luzio SD et al. (1989) Insulin deficiency in non-insulin-dependent diabetes. Lancet I: 293-295

7. Clark PM, Levy JC, Cox L, Burnett M, Turner RC, Hales CN (1992) Immunoradiometric assay of insulin, intact proinsulin and 32-33 split proinsulin and radioimmunoassay of insulin in diet-treated type 2 (non-insulindependent) diabetic subjects. Diabetologia 35: 469-474

8. Sicree RA, Zimmet PZ, King HOM, Coventry JS (1987) Plasma insulin response among Nauruans: prediction of deterioration in glucose tolerance over 6 yr. Diabetes 36: 179-186

9. Saad MF, Knowler WC, Pettitt DJ, Nelson RG, Mott DM, Bennett PH (1988) The natural history of impaired glucose tolerance in the Pima Indians. N Engl J Med 319: 1500-1506

10. Haffner SM, Stern MP, Mitchell BD, Hazuda HP, Patterson JK (1990) Incidence of type II diabetes in Mexican Americans predicted by fasting insulin and glucose levels, obesity and body-fat distribution. Diabetes 39: 283-288

11. Lundgren H, Bengtsson C, Blohmé G, Lapidus L, Waldenström J (1990) Fasting serum insulin concentration and early insulin response as risk determinants for developing diabetes. Diabetic Med 7: 407-413

12. Eriksson J, Franssila-Kallunki A, Ekstrand A et al. (1989) Early metabolic defects in persons at increased risk for non-insulin-dependent diabetes mellitus. N Engl J Med 321: 337-343

13. Dowse GK, Zimmet PZ, Finch CF, Collins VR (1991) Decline in incidence of epidemic glucose intolerance in Nauruans: implications for the "thrifty genotype". Am J Epidemiol 133: 1093-1104

14. Zimmet PZ, Collins VR, Dowse GK, Knight LT (1992) Hyperinsulinaemia in youth is a predictor of type 2 (non-insulin-dependent) diabetes mellitus. Diabetologia 35: 534-541

Dr. G. K. Dowse

International Diabetes Institute, 260 Kooyong Road

Caulfield Vic 3162, Australia 


\section{Response from the authors}

Dear Sir,

We thank Drs. Dowse et al. for their comments on our "thrifty phenotype" hypothesis and the opportunity to address the questions which they pose.

There is now a large measure of agreement that the pathogenesis of Type 2 (non-insulin-dependent) diabetes mellitus involves a varying combination of defective insulin secretion and insulin resistance. Caucasians with Type 2 diabetes seem to be heterogeneous. Some exhibit only an insulin secretory defect while others, who often have abdominal obesity, show both defective insulin secretion and insulin resistance [1,2]. In other populations insulin resistance may be dominant. There is, however, substantial evidence that a defect of insulin secretion often precedes the development of Type 2 diabetes $[2-10]$.

Dowse et al. suggest that raised fasting and/or raised 2-h plasma insulin concentrations are evidence of good beta-cell function. We do not accept this. Small elevations of fasting "insulin" measured non-specifically may be due to elevated concentrations of proinsulin-like molecules. Also beta-cell dysfunction is associated with loss of the normal oscillatory pattern of insulin secretion in the fasting state [11] which may reduce the biological effectiveness of the secreted insulin and hence lead to raised fasting insulin concentrations. Raised 2-h plasma insulin concentrations are often secondary to a poor early insulin response to oral glucose [12]. They may therefore be a sign of beta-cell dysfunction rather than "high" beta-cell function.

Dowse et al. believe that our hypothesis cannot explain the "specific lesion" of loss of first phase insulin secretion. We find nothing particularly specific in this change since it is also seen prior to the onset of Type 1 (insulindependent) diabetes [13] and after partial pancreatectomy $[14,15]$.

We recently showed in our study of men from Hertfordshire that men with impaired glucose tolerance or Type 2 diabetes tended to have low birthweight and low weight during infancy [16]. We confirmed this finding in a second study of men and women living in another part of Britain [17]. This second study showed that the association with low birthweight depended on reduced fetal growth rather than premature birth. Our hypothesis is that both poor beta-cell function in adult life and insulin resistance are associated with retarded early growth. Animal studies provide strong evidence that poor fetal and infant nutrition can permanently impair insulin secretion. Evidence that retarded early growth is linked to insulin resistance comes from the association of low birthweight and infant weight with syndrome $X$ [18], of which insulin resistance is an important component. A recent study using insulin tolerance tests showed that adults who were thin at birth were more insulin resistant as adults (D.I.W.Phillips, D.J.P.Barker and C.N. Hales, unpublished observation).

Though we misunderstood the explanation for the decline in Type 2 diabetes in Nauruans [19] our point still stands. Our hypothesis suggests that an improvement in nutrition in a previously malnourished population will lead, through improved growth of the fetus and infant, to a reduction in the incidence of Type 2 diabetes in later generations. Future studies should investigate such a possibility rather than seeking only genetic explanations of changes in incidence and prevalence.

We hope that these explanations and our continuing research will help to give the support for our hypothesis that Drs. Dowse, Zimmet and Alberti seek.

Yours sincerely,

C. N. Hales and D.J.P. Barker

\section{References}

1. Arner P, Pollare T, Lithell H (1991) Different aetiologies of type 2 (non-insulin-dependent) diabetes mellitus in obese and non-obese subjects. Diabetologia 34: 483-487

2. Ward WK, Johnston CLW, Beard JC, Benedetti TJ, Porte D Jr (1985) Abnormalities of islet b-cell function, insulin action, and fat distribution in women with histories of gestational diabetes relationship to obesity. J Cin Endocrinol Metab 61: 1039-1045

3. Ward WK, Johnston CLW, Beard JC, Benedetti TJ, Halter JB, Porte D Jr (1985) Insulin resistance and impaired insulin secretion in subjects with histories of gestational diabetes mellitus. Diabetes 34: 861-869

4. Dornhorst A, Edwards SGM, Nicholls JSD et al. (1991) A defect in insulin release in women at risk of future non-insulin-dependent diabetes. Clin Sci 81: 195-199

5. Kühl C (1991) Insulin secretion and insulin resistance in pregnancy and GDM. Diabetes 40 [Suppl 2]: 18-24

6. Omori Y, Minei S, Uchigata Y et al. (1991) Comparison of diagnostic criteria of IGT, borderline and GDM. Diabetes 40 [Suppl 2]: 30-34

7. O'Rahilly SP, Nugent Z, Rudenski AS et al. (1986) Beta cell dysfunction rather than insulin resistance is the primary defect in familial non-insulindependent diabetes. Lancet I: 360-363

8. Kosaka K, Hagura R, Kuzuya T (1977) Insulin responses in equivocal and definite diabetes, with special reference to subjects who had mild glucose intolerance but later developed definite diabetes. Diabetes 26: 944-952

9. Lundgren K, Bengtsson C, Blohme G, Lapidus L, Waldenstrom J (1990) Fasting serum insulin concentration and early insulin response as risk determinants for developing diabetes. Diabetic Med 7:407-413

10. Skarfors ET, Selinus KI, Lithell HO (1991) Risk factors for developing non-insulin dependent diabetes: a 10 year follow up of men in Uppsala. $\mathrm{Br}$ Med J 303: 755-760

11. O'Rahilly S, Turner RC, Matthews DR (1988) Impaired pulsatile secretion of insulin in relatives of patients with non-insulin-dependent diabetes. N Engl J Med 318: 1225-1230

12. Mitrakou A, Kelley D, Mokan M et al. (1992) Role of reduced suppression of glucose production and diminished early insulin release in impaired glucose tolerance. N Engl J Med 326:22-29

13. Tarn AC, Thomas JM, Dean BM et al. (1988) Predicting insulin-dependent diabetes. Lancet I: 845-850

14. Kendall DM, Sutherland DER, Najarian JS, Goetz FC, Robertson RP (1990) Effects of hemipancreatectomy on insulin secretion and glucose tolerance in healthy humans. N Engl J Med 322: 898-903

15. Stagner JI, Samols E (1991) Deterioration of islet b-cell function after hemi-pancreatectomy in dogs. Diabetes 40: 1472-1479

16. Hales CN, Barker DJP, Clark PMS et al. (1991) Fetal and infant growth and impaired glucose tolerance at age 64 years. Br Med J 303: 1019-1022

17. Phipps K, Barker DJP, Hales CN et al. (1992) Fetal growth and impaired glucose tolerance in men and women. Diabetologia 36: 225-228

18. Barker DJP, Hales CN, Fall CHD, Osmond C, Phipps K, Clark PMS (1992) Type 2 (non-insulin-dependent) diabetes mellitus, hypertension and hyperlipidaemia (syndrome X): relation to reduced fetal growth. Diabetologia 36: $62-67$

19. Dowse GK, Zimmet PZ, Finch CF. Collins VR (1991) Decline in incidence of epidemic glucose intolerance in Nauruans: implications for the "thrifty genotype". Am J Epidemiol 133: 1093-1104

Prof. C.N.Hales

Department of Clinical Biochemistry

Addenbrooke's Hospital

Hills Road

Cambridge CB2 2QR

UK 